\title{
The History of the NAH Central Building's Construction
}

\author{
TIBOR CSABA REISZ, PH.D. \\ National Archives of Hungary, Bécsikapu tér 2-4, 1014 Budapest, Hungary \\ e-mail: reisz.t.csaba@mnl.gov.hu
}

The History of the NAH Central Building's Construction

\begin{abstract}
The first place to keep the documents with national importance was the Archivum Regni founded in 1756 based on the Act XLV of 1723. By its reorganisation the National Archives was founded in 1874, which operated as the source reserve for the science of history. Since the very beginning the archivists claimed, that the institute should work in a separate building that represents the value of the science with its appearance. The study describes how the construction was completed from the idea until the completion of the Palace of the National Archives. The importance of the construction comes from the fact that it had been the first building in Hungary that was planned and built specifically for the needs of an archives. During the preparation period the leading employees of the archives visited several European archives, wrote detailed reports about the experienced technical and organisational solutions. Due to restrictions of length the study concentrates on the introduction of the experiences of the study tours abroad. During the planning the warehousing, researching, fire safety, operational, and aesthetic features were all considered. However, negotiating the finances forced the decision makers to leave out some of the aims, and make compromises. The construction started in 1913, and should have been finished by the middle of 1916, however due to WWI the building was completed in 1918, its internal decorations were only ready by 1929 , and it was used for exclusively archival purposes only after 1945. The preparation, construction and the history of the building supplies us with useful experiences when planning state-of-the-art archival buildings.
\end{abstract}

Il processo di costruzione dell'edificio dell'Archivio centrale nazionale ungherese.

\section{SINTESI}

Il primo posto dove conservare i documenti con rilevanza nazionale è stato l'Archivum Regni fondato nel 1756 e basato sul XLV Act del 1723. Dalla sua riorganizzazione è stato fondato l'Archivio nazionale nel 1874, che ha funzionato come riserva per la scienza storica. Fin dall'inizio gli archivisti hanno sostenuto che l'Istituto avrebbe dovuto funzionare in un edificio separato. Il presente studio descrive come la costruzione venisse completata dall'idea originale fino alla realizzazione del Palazzo degli archivi nazionali. L'importanza della costruzione deriva dal fatto che è stato il primo edificio in Ungheria progettato e costruito appositamente per le esigenze di un archivio. Durante il periodo di preparazione i dipendenti degli archivi hanno visitato parecchi Istituti europei, scrivendo delle relazioni sulle soluzioni tecniche ed organizzative. Il presente studio si concentra sull introduzione delle esperienze dei viaggi di studio all'estero. Durante la pianificazione del magazzino, erano tutte considerate ricerca, sicurezza antincendio, caratteristiche funzionali ed estetiche. Tuttavia, le finanze hanno costretto a lasciare fuori alcuni degli obiettivi ed hanno costretto a dei compromessi. La costruzione iniziata nel 1913 avrebbe dovuto esser finita entro la metà del 1916, tuttavia a causa della prima guerra mondiale l'edificio fu completato nel 1918, le sue decorazioni interne furono pronte solo nel 1929, ed è stato usato per scopi di archiviazione esclusivamente solo dopo il 1945. La preparazione, la costruzione e la storia dell'edificio ci forniscono esperienze utili per la pianificazione di edifici d'archivio.

\section{Zgodovina gradnje centralne stavbe Narodnega Arhiv Madžarska}

\section{IZVLEČEK}

Prvi kraj za hrambo gradiva državnega pomena je bil kraljevi arhiv Archivum Regni ustanovljen leta 1756 na podlagi zakona Act XLV iz leta 1723 . Z reorganizacijo je bil ustanovljen nacionalni arhiv leta 1874 , in je predstavljal skladišče virov zgodovinski znanosti. Že od samega začetka so arhivisti opozarjali, da bi inštitut moral delovati v ločeni stavbi, kjer bi predstavljal znanost s svojim videzom. Prispevek opisuje, kako se je odvijala gradnja državnega arhiva od idejne zasnove do končne izgradnje palače nacionalnega arhiva. Pomen gradnje je viden v dejstvu, da je to bila prva zgradba na Madžarskem, ki je bila namensko načrtovana in zgrajena za potrebe arhiva. $V$ času priprav so vodstveni delavci arhiva obiskali nekoliko evropskih arhivov in napisali podrobna 
poročila o tehničnih in organizacijskih rešitvah. Zaradi omejitve dolžine, se prispevek osredotoča na nabiranju izkušenj pri študijskih poteh v tujini. Med načrtovanjem je bilo zajeto vse, od skladišč, raziskovanja, požarne varnosti do funkcionalnost in estetskega videza. Pogajanja glede financiranja so prisilila vodilne, da so pri sprejemanju odločitev izpustili nekatere zahteve in pristali na kompromise. Gradnja je začela leta 1913 in bi se morala končati do sredine leta 1916, vendar je bila gradnja zaradi Prve svetovne vojne končana leta 1918, notranja ureditev pa je bila končana šele 1929. Izrecno v arhivske namene se je uporabljala šele po letu 1945. Priprave, gradnja in zgodovina gradbenega materiala nam podajajo koristne izkušnje pri načrtovanju umetniških arhivskih zgradb.

A Magyar Országos Levéltár központi épületének építéstörténete

\section{ÖSSZEFOGLALÓ}

Az 1723. évi XLV. törvénycikkel létrehozott, ténylegesen 1756-ban felállított Archivum Regni volt az országos jelentőségű iratok első őrzőhelye. Ennek átszervezésével 1874-ben hozták létre az Országos Levéltárat, amely már a történettudomány forrásőrző helyeként működött. Szinte a kezdetektől igényelték a levéltárosok, hogy az intézmény önálló - és lehetőleg a tudományág jelentőségét hangsúlyozó reprezentatív - épületben működhessen. A tanulmány bemutatja, hogy a gondolattól a megvalósulásig hogyan alakult az Országos Levéltár palotájának építéstörténete. A ház elkészitésének jelentőségét az adja, hogy Magyarországon ez volt az első olyan épület, amelyet eredetileg is levéltári szakmai feladatokra terveztek és építettek meg. A levéltár vezető munkatársai az előkészületek során számos európai levéltári intézményt kerestek fel, és részletes jelentést készítettek az ott tapasztalható műszaki és üzemszervezési megoldásokról. A tanulmány a terjedelmi korlátok miatt a külföldi tanulmányutak tapasztalatainak ismertetésére helyezi a hangsúlyt. Az épület tervezésekor a raktározási, kutatói, tüzvédelmi, múködtetési és esztétikai szempontokra is figyelemmel voltak. A kivitelezés költségvetése már kompromisszumokra és egyes célok elhagyására késztette a döntéshozókat. Az építkezés 1913-ban kezdődött és 1916 közepére befejeződött volna, de a világháború eseményei miatt az épület 1918-ra készült csak el, belső díszítésével 1929-ben végeztek, és teljes egészében levéltári célokra csak 1945 után vehették használatba. Az előkészítés, kivitelezés és sorstörténet a mai levéltári épületek elkészítéséhez is tanulságul szolgál.

The construction work of an archival building requires a lot of time, money and professional work of several players, even at present. The political, communication and travel possibilities offer much favourable conditions for the planning and preparation phases than as they were given for our ancestors a century ago. How could the archivists collect experiences about the construction of a new archival building, when there had not been any such buildings constructed ever before? The current study processes one of the phases of the history of the first building of the National Archives of Hungary (NAH), namely the study tours abroad, due to restrictions of length.

Regarding the foundation of the new National Archives as a new institute (1874) Miskolczy Gyula and Dőry Ferenc wrote studies based on documents and personal experiences, the former only slightly touching the subject, while the latter specifically concentrating on the building. On the 100 year anniversary of the institute Borsa Iván wrote about the history of the archival buildings based on the same sources. The studies written later also build on the above mentioned sources ${ }^{1}$. The contemporary documents regarding the construction of the building of the new National Archives is stored quite chaotically, that is quite difficult to research, in two fonds among the documents of the Ministry of Interior as well as NAH. Their exploration and research was started in 2013 by the author ${ }^{2}$.

\section{The Foundation of the National Archives}

The Hungarian Kingdom considerably weakened politically by the beginning of the $16^{\text {th }}$ century, the internal conflicts as well as the increasing pressure of the Ottoman Empire had broken the

\footnotetext{
1. Miskolczy Gyula (1923). Az országos levéltár felállítása [The Establishment of the National Archives]. Levéltári Közlemények, 1(1-2) pp. 6-24. Dőry Ferenc (1924). Az új országos levéltár megépítése [Construction of the New National Archives]. Századok, 57. pp. 403-417. Borsa Iván (1979). Az Országos Levéltár épületei, 1874-1974. [The buildings of the National Archives, 1874-1974]. Levéltári Közlemények, 50(1) pp. 23-50.

2. The locality of the records is: Magyar Nemzeti Levéltár Országos Levéltára [National Archives of Hungary, Central Archives = NAH CA], K 148. Belügyminisztérium [Ministry of Interior], Elnöki iratok [Presidialia], 1922. 14. tétel (fascicles 725-735.), and Y 1. Magyar Országos Levéltár Levéltára [Archives of NAH CA], Általános iratok [General records], 1875-1944. (fasc. 210.). Few records were used by Patakiné Kósa Éva (1997). Magyar Országos Levéltár. Budapest.
} 
country. It broke into three parts, in which different political, social and economic development could be detected. The depression had effected the operation of the state institutes, and although new institutes (lieutenancy, chamber, court council of war) were founded, some old ones were closed down. The Medieval Royal Archives was lost during the escape after the defeat at Mohács, while the codices of the royal library disappeared during the liberation of Buda at the end of the $17^{\text {th }}$ century ${ }^{3}$.

The documents with national importance were kept by the noblemen: the chancellor, bishops, military leaders, and since 1608 the palatine together with their own private archives. During the diets of the $17^{\text {th }}$ century (in $1613,1622,1625,1645,1649,1655$ ) the palatine's relatives or widow were asked or acknowledged to hand over the documents with national importance. In 1681 the chest with the national archives was searched and found. In 1701 the foundation of the national archives as an institute was initiated, palatine Esterházy Pál suggested that a new parliament should be constructed where these documents could be kept. Eventually the national archives was founded in the house of the diet in Pozsony/Bratislava in 1723 (Act LXV.), which started its real operation in $1756^{4}$. However, at that time the Archivum Regni was still not an open scientific institute, but the official place of the national documents that operated in the Houses of Parliament.

During the revolution and war of independence in 1848-1849, and after its suppression during the Austrian neo-absolutism the feudal states were abolished and the new, civilian state was started to be created. The political consolidation was accomplished by the Austro-Hungarian Compromise in 1867 , the development of the country gained new perspectives. The tasks of the old feudal institutes were taken over by the civil state polity, the old national documents were brought to the memories of the past from the scenes of the daily operations. Based on the Archivum Regni the National Archives was founded as a new institute in 1874, which is the legal predecessor of the current NAH, which operated under the supervision of the Ministry of Interior until 1922.

\section{Attempts to Construct an Individual Archival Building}

During feudalism the national, county and city archives did not operate in separate buildings, but in the official buildings of their finance providers (the house of the parliament, the county hall, the city hall), mainly in the basement or on the ground floor. These areas had not been constructed for archival purposes, so even in those years they were considered as inappropriate.

To construct an individual archival building was initiated at the very moment of the foundation plans of the national archives of the civil era, in 1868, and during the following four decades the allocation of the archives and the renewal of the earlier attempts were endeavoured several times. The great number of failed attempts of the solution represents the weakness of the concerned ministers and officials.

The diet, and then its financial committee wanted to achieve to have all the documents kept on one place, especially the ones kept in Vienna and in Transylvania. This attempt also represented the desire for the independent Hungarian status. The Minister of Interior responsible for the archives always underlined that the available spaces were not sufficient, neither was their quality, and he suggested new halls, or rather the construction of a new building. However, the Minister of Interior did not insisted on this suggestion, since when the ministry was offered to get a new palace he wanted to move the archives there instead of a new building. The Prime Ministers supported the construction of a new archival building primarily because they wanted the documents kept abroad to be taken home and placed in the new archives. The Minister of Finance wanted to harmonise the several needs of the different national institutes and offices, thus he several times objected the construction of a new building, and he wanted to submit some freed areas after moving other offices for archival use.

\footnotetext{
3. About the history of the archives see: Dóka Klára et al. (2000). A magyar levéltártörténet kronológiája, 1000-2000 [Cronology of the History on the Hungarian Archives, 1000-2000]. Budapest. The newest about the history of NAH: Lakos János (2006). A Magyar Országos Levéltár története [History of NAH]. Budapest.

4. 1723. Art. LXV. "Ut universale archivum regni, pro interim in libera, et regia civitate Posoniensi, et in domo dominorum regnicolarum instituatur; ad quod publica regni acta, et diaetalia, et alia politica, et juridica prae manibus quorumcunque habita, sive etiam in capitulis, et conventibus conservata, seu apud privatas familias reperibilia, et publicum regni statum tangentia, ad summum intra anni spatium, per manus ordinandi archivi conservatoris reponantur". Corpus Juris Hungarici. Magyar törvénytár. 1657-1740. évi törvényczikkek. Budapest, 1900. p. 606.
} 
Even during the foundation of the national archives (1868-1874) the idea of the proper placement of the archives continually expanding with the inclusion of the feudal documents occurred ${ }^{5}$. The Minister of Interior asked to postpone the transportation of the documents due to the bad circumstances (wet, damp basement, insufficient and inappropriate other areas), as long as sufficient amount of empty rooms or a newly constructed archival building is available. Later the minister suggested the construction of a new building several times $(1871,1874)$. In autumn 1872 a special committee (from officiers and archivists) was initiated that proposed the temporary allocation of the archives ${ }^{6}$. On the meeting of the committee historian Horváth Mihály suggested that since there was no literature about the operation of an archives in Hungary, the director of the national archives should study the operations of the archives in Munich, Paris, Brussels and probably in Florence, and to get the operational regulations of the earlier mentioned archives ${ }^{7}$. Obviously this suggestion mainly focused on the organisational matters, however it might have touched the circumstances of the allocation as well.

Dr. Pauler Gyula (1841-1903) lawyer and historian was appointed the director of the national archives by the monarch on $14^{\text {th }}$ October 1874 , who filled this position until his death. The institute was founded - basically in theory, its real definition and organisation was left for the coming years. The new director took a European study tour between $7^{\text {th }}$ December 1874 and the beginning of February 1875 , during which he visited the national archives in Brussels, Berlin, Vienna, Dresden, the Hague and France, his report was completed on $27^{\text {th }}$ March 1875. During the tour Pauler studied mainly the organisation of the archival institutes (the place of the national archives in the public administration, its relation to the county archives, the professional staff, the areas, the quantity of the materials, their expansion or decrease, the safekeeping of the documents, and their use were the basic aspects of research). The archives operated segmented in different areas of the Ministry of Interior that were not suitable for archival purposes, among quite bad conditions.

The thought of the construction of a new archival building turned up again between 1897 and 1901. The allocation of the newly founded Administration Court and the National Archives was initiated in the old building of the Ministry of Religion and Public Education by building an additional floor. The Minister of Commerce already ordered the planning of the expansion of the building, when the Minister of Finance changed his mind: he wanted to place the court in the new palace of the Ministry of Finance, and the archives would have got the areas of the court. The Minister of Interior did not agree with this solution. Due to the unacceptable conditions of the allocation the otherwise modest director Pauler strongly urged the construction of a new building, and the suggestion was conveyed to the Prime Minister by the Minister of Interior with his own support ${ }^{8}$. The Prime Minister urging to take the national documents home from Vienna had already been committed to the issue of the archives, told the Minister of Interior that only a new building could solve the problems of the archives?. Finally on $10^{\text {th }}$ March 1899 the Minister of Finance agreed to finance the construction of the new palace of the archives and the preparation of the necessary studies. Based on it the Minister of Interior sent Pauler Gyula on a European study tour (see in the following).

In his proposal to Prime Minister Széll Kálmán on $6^{\text {th }}$ May 1899 Pauler initiated the realisation of the previous suggestions, that is to ask Pecz Samu, the professor of public constructions at the University of Technology to prepare the plans for the archival building. After obtaining the higher permissions the Director asked Pecz to fulfil the task on $26^{\text {th }}$ May 1899, and he accepted the offer. Since that time the architect spent years with the preparation of newer and newer plans designed to the different

\footnotetext{
5. The data regarding the construction of the archives' palace was mainly taken from the already cited work by Döry Ferenc, I do not mark them separately.

6. The summary of the proposals of the committee appeared in printed form as well: Az államlevéltári enquête javaslata. [Proposition of the enquête on the state archives.] Századok, 8(1) pp. 1-8.

7. Miskolczy, 1923. p. 14.

8. On $15^{\text {th }}$ February 1899 Pauler Gyula asked the Minister of Interior in his report: "I am begging again the construction of a separate archival building, in which matter the Romanians for example have outdistanced us in Bukarest, and which will stand as a memorial construction of that person who completes it in the history of our culture. That is why you are begged to complete as soon as possible, rather than postpone it". NAH CA, K 148. 938/1899. BM (726. cs.).

9. Prime Minister baron Bánffy Dezső to Minister of Finance Lukács László on $18^{\text {th }}$ February 1899: “Almost every important country and even city of Europe has erected a separate palace matching the needs of safekeeping, to keep their important documents regarding their history, and it is necessary that we would not procrastinate." NAH CA, K 148. 1482/1899. ME (fasc. 726.).
} 
building site proposals ${ }^{10}$. After the appointment of a new Prime Minister the Minister of Finance made a new proposal: he wanted to supply the archives with a new place in the basement of the almost finished new parliament building. This proposal ceased the planning of a new building again.

During a new period of targeting the construction of a new archival building (1902-1903) the Minister of Interior initiated that the costs of the new archival building should be included in the investment budget proposal of the state buildings, and at the same time he made a proposal for a new building site. The Ministry of Finance did not even decide about the previous proposal when the Ministry of Interior changed its proposal and wanted to allocate the archives within the palace of the Ministry giving up the idea of a new archival building, and asking for the redistribution of the budget amounts in the favour of the new Ministry palace. Neither the ministry nor the archives got new buildings.

After the previous unsuccessful periods, between 1904 and 1907 the case of the separate archival building advanced at least on theoretical levels. The government gave up on the construction of a new Prime Ministry building in favour of the construction the new archival building. On $12^{\text {th }}$ December 1904 the Minister of Interior established a construction committee that proposed on its first and at the same time its last meeting on $25^{\text {th }}$ February 1905, that before the planning activities, Pecz Samu should make a European study tour together with some archival experts (its description see in the followings). However, due to the internal crisis of the Hungarian politics in 1905 and 1906 and the temporary disability of the governmental activities although the report of the committee had been completed by the beginning of 1906 the government had more important tasks to stabilize the work of the government and the political leadership. At the same time however the participants of the study tour completed tasks later during the realisation of the archival building, thus their experiences were not lost.

Finally the construction of the building of the National Archives can be linked to the era of a new director, Csánki Dezső (1911-1932). Csánki was able to draw the attention of count KhuenHéderváry Károly, who was deeply interested in history, and he eventually really supported the construction of the new palace. In spring 1911 the meeting held in the Ministry of Finance decided about the construction of the national archival building as the first priority, and at the same time the building sites were also defined (this area was different from the previous proposals) ${ }^{11}$. Pecz Samu prepared the plans of the new building again. The Ministry of Interior established a new construction committee, which made several alterations of the plans that the architect applied, on its four meetings $\left(3^{\text {rd }} \mathrm{July}, 7^{\text {th }}\right.$ September, $4^{\text {th }}$ October, $20^{\text {th }}$ November 1911). The construction work started in October 1913 - with demolition work - and it should have been completed by $1^{\text {st }}$ May 1916. The outburst of WWI set the work back first by most of the building workers going to the front, and later by suspending the work for a period between $1^{\text {st }}$ September 1914 and $15^{\text {th }}$ March 1915. Later the lack of work forces as well as construction materials hindered the completion in time. The building was completed by 1918, however moving the archives in the palace was only completed in 1923 (some other offices and private families had to be moved out, and the necessary equipment had to be purchased), thus the National Archives has been operating in this building since then. The final completion, mainly the internal decorations could be completed by the effective political and financial support of count Klebelsberg Kuno, Minister of Interior, and later of Religion and Public Education. Thus the palace was completed by 1929. Although WWII and the 1956 revolution caused serious damages to the building as well as the documents, the National Archives still operates in the same palace built for archival purposes.

\footnotetext{
10. Due to his long work dedicated to the construction of the new archival building there was no public tender for the realisation, Pecz Samu became the leading architect. Unfortunately he died on $1^{\text {st }}$ September 1922 after spending 23 years on the task, and he could not see the total completion of the building and its inauguration.

11. The Council of Ministers decided to spend 40 million Crowns in 10 years for public constructions (on 10 ${ }^{\text {th }}$ May 1911 , point 70: the construction of the National Archives on Bécsi kapu Square, 16 ${ }^{\text {th }}$ December 1911, point 33: The sequence of public constructions). The construction of the archival building was considered as first priority, if possible in 19121914, the next one was the Central County Court (1912-1913), the Ministry of Justice (1913-1914), the Ministry of Interior (1914-1915) and the palace of the Ministry of Religion and Public Education (1915-1916), the Administration Court, the Ministry of Trade and the National Printing House.
} 


\section{The Study Tour of Pauler Gyula in 1899}

After the Minister of Finance gave permission for the preparations, director dr. Pauler Gyula was sent to a study tour to Germany by Széll Kálmán (Prime Minister and Minister of Interior) on $7^{\text {th }}$ April 1899. His report on the study tour was presented on $29^{\text {th }}$ April $1899^{12}$.

According to his report Pauler travelled to Vienna first on $10^{\text {th }}$ April, so that he could visit the plans of the new archives. The next day he travelled to Wrockaw, Poland, where he visited the not too valuable royal archives, built in 1877 , operating on old ways, and the city library, where the shelfcases made of iron panels on the most up-to-date way impressed him. In Dresden he visited the royal archives (old building with old system, the new building is only in planning phase) and the new Saxon Military Archives. The latter was built based on the archival building in Weimar, and it was finished in 1897. The detached building stood in the middle of a park. On $14^{\text {th }}$ April he visited the famous library of the university in Leipzig, which was visited by everybody who wanted to build such buildings, he found it attractive from outside, but not so practical inside. On $16^{\text {th }}$ and $17^{\text {th }}$ April he visited the archives in Weimar considered as the "master-gauge", its building stood in a small, quiet, dust-free square, detached, warehousing was completed on magazine system, where there were iron grid cases and impregnated wooden shelves in the repository. It was considered as the perfect type of the archival buildings, however the director would have done some things differently at that time, and he suggested that Pauler should visit the new building of the archives in Strassburg, where that system was further developed. The next day Pauler travelled to Strassburg where he visited the Lower-Saxon Archives, which was built on the corner of two streets, isolated, in a park, where expansion was possible, in 1896. The internal system of the repository was a magazine system with six-storey iron grid corridors with impregnated wooden shelves. Due to the Bavarian traditions the archival repositories, the offices and the flats were not separated by fire walls, but were detached buildings, and only a corridor linked them. Then he returned to Vienna for some short discussion, and then travelled home. In his report Pauler mentioned that he was warmly welcomed everywhere, he did not have to use the letter of the Ministry of Foreign Affairs, the archives were open to supply any information, and even their plans were made available.

Based on his experiences Pauler Gyula - stating that each archival building has to be constructed individually according to the available materials, their quality and quantity, thus the mindless copying is not an option - identified the general conditions of the new archival building as follows:

1. The building should stand isolated on a plot that is far from other buildings regarding fire safety, and where expansion is possible. It has to be dust-free, and not subject to floods (that is why he excluded Pest), it should be close to the Ministry of Interior, in easy reach for the public.

2. The archival repositories and the official areas (including the flats of the stoker, the servant and the director) should be separated by fire walls, or even better if they are detached connected by only a corridor.

3. The magazine system should be used for keeping the documents that is all the shelf cases should be 2.25 to 2.5 metres tall, so that the documents could be taken off even from the top shelf. The cases can be made of iron grids or impregnated wood. The light and the circulation of the air has to be supplied in the corridors. The repositories should face the south.

4. The shelf cases have to be separated by walls both vertically and horizontally to separate the space for fireproof areas. Thus the danger can be easier localised.

5. Water pipes and electricity should be there on each floor, the latter is needed in case of danger at night.

6. Each room has to be supplied with central steam heating, at least $10^{\circ} \mathrm{R}^{13}$ has to be in the repositories so that work would be possible and for the safekeeping of the documents.

7. Elevators suitable for transporting the documents are necessary.

8. A main hall is necessary for the already existing and expanding exhibition and for other celebrations. 


\section{The Trip of Pecz Samu and the Archivist Experts, 1905}

Pecz Samu (1854-1922), the professor of the Technical University actively participated in the planning and construction phases of the new archival building for more than two decades since spring $1899^{14}$. He again and again re-planned the archives as new building plots - almost ten - were proposed, implementing the ideas of the evaluating committees, and finally he led the construction work himself.

At the end of 1904 the Minister of Interior formulated an archival construction committee, its members were officials of the ministry (the state secretary chairing as the president), and archivist experts like Thallóczy Lajos, the director of the archives of the Common Ministry of Finance, Károlyi Árpád, the vice-director of the Home, Court and State Archives, Óváry Lipót, the leader of the National Archives (1904-1908) and Pecz Samu architect ${ }^{15}$. The committee had only one meeting. They stated that it is absolutely necessary to build a new archival building, "the national archives that contains national public treasures is prone to demolition due to the unsuitable condition how they are kept in damp, fire hazardous areas, and moreover there will not be enough space for the allocation of the expected increased amount of documents". They stated that the 3 or 4 times bigger area than the originally planned $5,000 \mathrm{~m}^{3}$ would be necessary and "moreover possibilities for expansion are also needed, as the moving of the documents would cause a lots of trouble, and even damage". The committee liked the earlier plans of Pecz Samu, however they wanted the organisation and the equipment of the famous foreign archival buildings to be concerned, that is why they proposed that the architect and archivist experts should take a study tour on eight venues (the National Archives in Weimar, the Provincial archives in Strassburg, the Military Archives in Dresden, the National Archives in Leipzig, the Home, Court and State Archives in Vienna, the libraries in Basel and Paris, and the British Museum), and then they should prepare a report about their experiences that they have to present to the Minister of Interior.

On $31^{\text {st }}$ March 1905 Óváry Lipót director informed Prime Minister count Tisza István that he would include two leading archivist colleagues in the work, since "the research of the organisation and the equipment of the famous foreign archives could be more successful working together". According to the director, "the study tour should concentrate not only on the architectural concerns, but also should deal with such archivist questions that will be possible to solve in the future by the construction of the new National Archives building. Thus besides the studying the different systems used for storing the documents, and other new features, other aspects can be studied as well: storing the maps, stamps, facsimiles, rare documents, etc., equipment for photography, archival exhibitions, research halls and professional libraries, trainings and professional, expert surveys" ${ }^{\prime 6}$. They also recommended to visit Berlin and Munich, but not the British Museum "as it is only historicum".

The study tour was fulfilled in two phases as the director informed the Minister of Interior in details $s^{17}$. The first study tour was taken between $14^{\text {th }}$ and $25^{\text {th }}$ July 1905 , Pecz Samu was accompanied by Thallóczy Lajos and Károlyi Árpád visiting the archives in Basel, Strassburg and Karlsruhe. The second study tour was made between $12^{\text {th }}$ and $26^{\text {th }}$ September, this time the archivists of the National Archives (Óváry Lipót, Csánki Dezső, Tagányi Károly, Dőry Ferenc) took turns to accompany Pecz Samu to the archives in the different cities: to Vienna, Dresden (where they did not see anything new), they visited the university library in Leipzig, the archives in Weimar, the new iron-concrete archives of the Court of Auditors in Paris, the National Library and the National Archives. The archives of Foreign Affairs, and the two military archives in Paris were not researched as they did not have any modern features or solutions. They did not travel to England, where visiting the British Museum would not have been worth (it is well-known from the literature), "but to study the English National Archives (Public Record Office)'s exemplary building. However a thorough official description is available under the title of "An Account of the Construction of the Public Record Office and the means adapted for its security from fire, drawn up at the desire of the R[ight]. H[onourable]. Sir George Jessel, Master

14. At that time the Hungarian Royal Navy Academy (Fiume/Rijeka), the evangelic church in Nagyvárad (Oradea), the Evangelic Church and Secondary School in Fasor (Budapest), and some buildings of the Technical University in Budapest, with the central library among them were all build upon his plans.

15. NAH CA, K 148. 7257/1904. BM. (fasc. 726.)

16. NAH CA, Y 1. 464/1905. OL.

17. NAH CA, Y 1. 1524/1905. OL. 
of Rolls", with detailed pictures and drawings, thus getting this book the lack of the visit would be compensated" 18 .

Óváry Lipót presented his report about the study tour to the Minister of Interior on $6^{\text {th }}$ January 1906. The report gave a detailed description of the visited archives and libraries, with the main concern on the following aspects ${ }^{19}$ :

a) The building generally:

- its situation, environment (detached or built around),

- the size of the building site, the possibilities for expansion,

- the structure, segmentation, parts and inner design of the building,

- the situation of the different rooms, halls (entrance, hall, vestibule, stairs, attic, cellar, the flats of the servant, stoker, guard and warden),

- the height of the floors, the thickness of the slab, arches,

- architectural value (artistic effect), the style of the building, architectural solutions,

- construction costs;

b) The official areas (administrative rooms):

- the situation and the furniture of the office of the main archivist,

- the size and the furniture / equipment of the research hall (number of places for researchers),

- lighting (with natural light, gas or electricity),

- furniture,

- floor cover (linoleum),

- type of heating (low pressure steam or air heating, /medium pressure/ water heating) and its position (in the cellar);

c) Repository building / rooms:

- the connection between the repository and the main building (it is separated, linked by a corridor, separated by a fire-wall, built together),

- the doors of the repository,

- the sizes of the repository, the height and the number of the floors, the ways of separation (with iron grid, iron-concrete slab),

- the structure and the material of the shelf-cases (iron, wood), the material of the shelves (wood, impregnated wood), the size (length) of the shelves, the distance between the cases (aisle), the number of shelves, their distances from each other,

- the storage of the documents (racks, paper envelopes, wooden cases, iron chests on iron shelves, safe),

- vertical traffic, linking the floors, and the different parts of the building (stairs, lifts, hand operated elevators),

- type of heating (no heating, low pressure steam heating),

- daytime and artificial lighting (windows, slabs, electric lighting: with portable torches);

d) Peculiarities:

- meeting hall, collection of seals, collection of maps,

- workshops for photography and galvanplastics,

- storage of the maps,

- ventilation, fire safety,

- safety of documents, and other objects,

- short summary of the advantages and the disadvantages of the building.

18. The book was published by archivist and antiquary, Thomas Duffus Hardy (1804-1878) in 1876. No copy is known in Hungary, thus the desire of Óváry was not fulfilled.

19. Due to its length, we have to set aside from the publishing of this report. 
These aspects were not considered in case of each visited place, however they intended to make researches to each point. Further notices were taken regarding the individual institutes.

The National Archives of Basel (Staatsarchiv, Basel) was built as an extension of the city hall in 1898-1899, and it was the first building in Switzerland specifically built for archival purposes. The report underlined the artistic features of the building: the stylish decoration of the rooms, "it was made with relatively a few tools, but with great taste". They added, that the current main archivist's office was decorated with the portraits of his predecessors, which is also a sign of fine artistic taste. Regarding document safety they added, that the cabinets in the repository had been made of wood, although that should be the highest fire safety priority.

The two buildings of the regional archives in Stuttgart (Kaiserliches Bezirksarchiv, Stuttgart) (A repository and B administrative building) were constructed by Wilhelm Jerschke entrepreneur upon the plans of Maximilian Metzenthin, the Architect of the Government, who was helped by Samuel Landshut and Paul Cavael, who led the construction work between 1895 and 1896. At the beginning of the planning phase a second repository was also planned, however it was not built until Alsace became a French area.

The report underlined that "the repository of the archives stands separated from the administrative building, which is important concerning fire safety, lighting and ventilation." There was no cellar under the building, the structure of the slab was made of iron, and all wooden parts were replaced by other materials (iron, concrete). The advantage of the building was its careful and beautiful appearance, and that the buildings are detached, and the repository is separated. However they disapproved that the floors of the repository were separated by iron grids, which is an advantage concerning ventilation, but regarding fire safety and cleanliness it is not. This structure would be even more disadvantageous if the non-heated warehouse would be rebuilt with heating, "since the documents stored in the higher areas would dry out and become fragile due to the heat, not to mention the working conditions of the personnel."

The report added, that before they arrived there had been a big hail storm in Strassburg, which had broken the upper windows and the repository windows made with thin pane causing significant damage. Thus the roof windows should be avoided, the other windows have to be made of pane with the suitable thickness.

The building of the State Archives in Karlsruhe (Staatsarchiv, Karlsruhe) was specifically built for archival purposes and was finished in 1905. According to the report the research area was equipped with all the necessary things, there were even wardrobes and wash basins as well. They underlined, that there is modern heavy wooden furniture everywhere, the furniture of the main archivist's office are made of mahogany.

The Home, Court, and State Archives (Haus-, Hof-, und Staatsarchiv, Vienna) was constructed on the highest level of the technical standards of the era between 1899 and 1902. Its furniture and equipment were excellent. "The possibility for its completion was highly supported by the fact that the highest authorities had positive attitude concerning the project and the necessary finances were available for the experts working on it." - the report evaluated the reasons of success. Due to its closeness to NAH the report did not want to be too long and detailed, however this part was not shorter than the others ${ }^{20}$. The furnished exposition repository was separately mentioned in the report: on the $6^{\text {th }}$ floor the first 60 cases are designed to showcase the important documents under glass top.

The Royal Saxon Military Archives (Königliches Sächsische Kriegsarchiv, Dresden) was built in the second construction phase of the Albertstadt in 1896. After 1956 it became a part of the military library of the German Democratic Republic's army (National Volksarmee), and it was not open to the public. After the political changes in Germany and its reunion the building was used as National Archives.

This building was shortly described in the report, there was no heating or artificial lighting in the repository, no information was gained concerned the costs of the construction, the work itself was regarded as unambitious. (As Óváry Lipót wrote in his preliminary report, they did not see anything new here.) 
The building of the University Library in Leipzig was constructed in Italian renaissance style between 1887 and 1891, based on the plans of Arwed Roßbach (it is also called as Bibliotheca Albertina). According to the report it must have been a mistake that the itinerary stated that they had to visit a national archives here, later it was cleared that the archives had been initiated to be visited upon a false information. According to the report it is worth visiting the big libraries as well due to the several similarities between libraries and archives. "It is especially important when the palace to be built for the national archives of Hungary is concerned, as the archives build abroad have been constructed for small states, and they did not require such monumental solution as the building of the national archives." The air heating used in the building was considered inappropriate, since although air filtering system was used, it smudged the walls.

The building of the national archives in the Grand Duchy of Weimar was constructed in renaissance style between 1883 and 1885. It was built specifically for archival purposes based on the plans of Carl Heinrich Ferdinand Streichhan, for the first time in the German Empire.

According to the report "the really modern archival architecture was found first in Paris, since here instead of the earlier used halls system the magazin system construction was used". They visited the building of the Court of Auditors (Cour de comptes) constructed between 1845 and 1849, as well as the "Seine department". In 1871 siege of Paris the old archives burnt down together with the City Hall, that is why being so much afraid of fire the new archival building besides the River Seine had neither doors nor windows on the outer walls, only in the yards. These exaggerated precautions did not support the usage of the repository, since the halls were dark and the air was stale.

They also visited the building of the Bibliothèque nationale (1884), which supplied them with more experiences than the National Archives, as well as the new archival building of the Court of Auditors (Comptoir nationale, d'Escompte de Paris), which was constructed upon the plans of architect Constant Moyaux, this archives was the newest one in Paris at that time (1898-1905), and its special feature was that its shelf cases were not made of wood or iron, but iron-concrete. The report stated based on the opinion of the architect that iron-concrete is absolutely fire-proof, and more durable than the wooden and iron constructions, thus it is an extremely modern way. Its disadvantage is that the heights of the shelves cannot be adjusted, they are fixed, and that the construction is not light and clear as it would be in case of an iron structure.

Based on their experiences the experts completing the report - besides the generally accepted principle, that the archival building should stand unattached - the principles had been summarized in 15 points:

1. The official areas and the repository should be connected only by corridors, if it is not possible, fire walls have to be built.

2. For promoting quick and effective labour the block for administrative areas should only have a few floors.

3. The attic of the administrative building should be suitable for photo-workshop, as well as a galvanoplastic workshop.

4. The construction of too many floors in case of the repository should be avoided; maximum 8 floors should be built.

5. Every second floor of the repository should have a solid floor-space; the floors of the other floors should be rails or glass slab.

6. The structure of the repository should be made from concrete-iron, the shelves and their cases of iron.

7. The windows in the repository should be tall and narrow, placed quite close to each other, so that the aisles will be lighted by one window.

8. The height of the shelf cases should not exceed 2.35 metres, and the height of the repository floors should be planned accordingly.

9. Well sealed iron chests and boxes that are easy to move should be prepared for keeping the charters.

10. The repository should not have a glass roof.

11. Electric lightning should be provided in the repository, among the shelf cases hand lights have to be used. 
12. Heating should be provided by low pressure steam.

13. The hall for the preparation of charters should be allocated in the repository since the charters are the most precious documents.

14. In case the building lot will not be $100 \%$ used, the plans should be prepared so, that the repository could be expanded harmonically from architectural aspects, and the repository to be completed should also harmonize with the whole building.

15. The outer appearance of the building should match its purpose so that it would not obstruct the necessities of architectural aesthetics.

\section{SUMMARY}

However based on the Archivum Regni, the National Archives was totally re-organised in 1874. From the very beginning supplying the archives with the appropriate repository, research halls and offices for the placement, processing and research of the archived documents was first priority. During the search for a good solution some other options had also emerged, such as the allocation of the archives in other old or newly constructed public buildings (the Parliament, the palaces of different ministries), mainly in the basement. Eventually the proposal for a separate, new building came out as the winner. Due to the absolute lack of local experience the decision makers regarded the foreign study tours of the professionals as parts of the preparation activities. In 1899 the director, while in 1905 the leading architect and some archivist professionals visited the most modern archival buildings of the era. Their summary reports - their research aspects - reflect the high professional expertise and precision of the archivists of the era: safeguarding the documents, fire safety, and labour safety were all included in their research. Their research aspects, the thoroughness of their study can stand as an example for the archivists of our era as well, to enhance the complex mindset that is required when thinking of planning modern archival buildings. An additional lesson is the fact that almost all of their proposals were used in the plans of the National Archives.

Typology: 1.04 Professional Article

Submitting date: 08.03.2015

Acceptance date: 09.04.2015 
